THE MORAL

\section{JUSTIFIABILITY OF GENETIC MANIPULATION}

\author{
EVELYN PLUHAR \\ Pennsylvania State University
}

In my recent article, "On the Genetic Manipulation of Animals, "[1] I argued that although current genetic experiments on sentient non-human animals (hereafter, simply "animals") are ethically very questionable, it does not follow that genetic manipulation of animals is in principle wrong. If such manipulation were motivated by a thoroughgoing, responsible respect and concern for sentient individuals, I held, it could be morally justifiable. While Michael w. Fox has disagreed with some of my contentions, at botton we agree far more than we disagree. I an pleased to have the opportunity here to respond to him in turn.

Fox first takes issue with my claim that genetic manipulation is "not in itself cruel, nor need it lead to cruelty"[p. 14]. He quite rightly points out that experimentation on animals, in particular transgenic experimentation (in which genes from one species are inserted into another), when done purely for human benefit, is very likely to result in cruelty to animal subjects. I entirely agree with hin here, but to do so is no departure from my original contention. My point was that genetic manipulation as such is not the culprit. Genetic manipulation motivated by respect and concern for sentient individuals would probably not result in cruelty [see my p. 14].

Fox's second disagreement is with my claim that "genetic faming" is simply an extension of the traditional human manipulation of animal species for our own convenience [p. 13]. Fox claims that transgenic experiments are a different matter altogether, because "never before has it been possible to cross the genetic boundaries that keep individual species separate. I have two responses to make. (a) surely we have crossed these boundaries before. Consider,

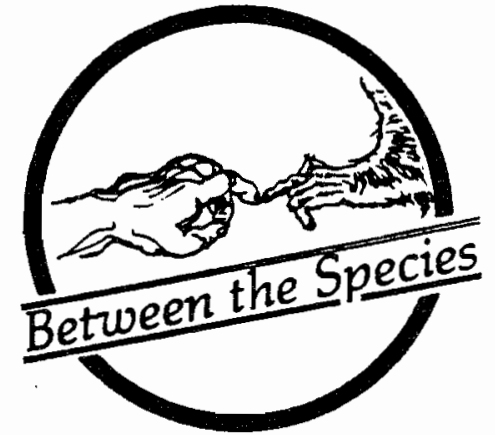

e.g., the tangelo and the mule.[2] of course, biotechnology now allows us to intermingle species which differ far more than the horse and the donkey, but this is a difference in degree (an "extension," as I said). (b) It also seems to me that the changes we have made within species by traditional nethods differ from the creation of hybrids only in degree. In all such cases, humans have intentionally altered the genetic makeup of animals. My point was-and is-that the alteration of non-human (or human) genetic make-up by humans, by whatever technologY, is not in itself wrong. It becomes wrong when sentient individuals are treated as mere means to our ends.

It is at this point that the one serious disagreement between myself and Fox emerges. He presses the following, third objection, according to which any alteration of genetic make-up would be unjustified: such tampering shows a disregard for the "telos" of animal species, and this is wrong because their "telos" is "to be respected and [is] worthy of moral consideration." This is an interesting and important challenge, but I will argue that it does not show genetic manipulation to be unjustifiable.

As Fox notes, the concept of "telos" is Aristotelian in origin, meaning (roughly) "final cause" or purpose. Although Fax urges us to grasp "the full and original meaning of "telos'," this is precisely what we would do well to avoid. Aristotle's "telos" is wedded to the anti-evolutionary view that species are fixed, inmutable, governed by intrinsic purposes. If we are to use the concept at all, we must up-date it as, e.g.., Bernard

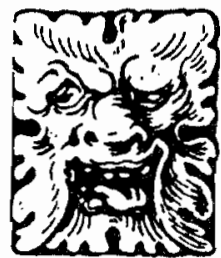

DISCUSSION 
Rollin has suggested: the "telos" of a living thing could be said to be its genetically encoded nature. [3] Fox follows this suggestion when he identifies "telos" with "the unique genetic make-up of species."

However, the up-dating of the soncept of "telos" which we are required to make renders it rather unsuitable for use by opponents of genetic manipulation. The genetic nake-up of an animal species is subject to alteration-sometimes gradual, sometimes radical (as evolutionary biologists now increasingly believe). Chance and natural selection shape the "telos" of animals, keeping it from being an inflexible pattern. Fumans also shape the "telos" of animals, by "artificial" selection and by alteration of the conditions for aninal survival. The only difference between the hurnan and the non-human contributions to animal "telos" is that the former is generally deliberate. It does not seem reasonable to conderan any intentional contribution to evolution while accepting all chance contributions (regardless of the considerable suffering the latter cause). Instead, we should condern ill-intentioned and ixresponsible contributions-and consider applauding responsible attempts to alleviate the suffering caused by chance (e.g., by correcting genetic defects responsible for thousands of diseases).

Moreover, it is far from clear that "telos" (in the post-Darwinian sense) is morally considerable. It is plausible to hold that sentient beings are morally considerable because they have interests. Their genetic make-up certainly sets the boundaries of those interests, but that does not mean that it--as opposed to the interests--is morally considerable. Rollin, for example, is driven to reject the moral considerability of "telos." Although he at one point suggests that genetically encoded "telos" is "deserving of moral concern,"[4] he denies that plants (which, of course, have their "telos") are morally considerable, because they lack interests, [5] concluding that "any living thing, in so far as it evidences interests . . is worthy of moral concern."[6] Perhaps this is mistaken, and a case could be made for the moral considerability of everything with "telos," but it is not at all clear that this could be done.

Finally, if one wished (although I do not), one could actually make a good case in terms of post-Darwinian "telos" for certain kind of genetic manipulation. It is estimated that 1986 will be the year in which scientists will try to use genetic engineering to correct genetic defects in humans. [7] "Good" (although in a sense alien) genetic material will be substituted for "defective" material. We could easily describe this procedure as a restoration of "telos:" i.e.., the person will be allowed to have the genetic make-up he or she would have had if "errors," as scientists put it, had not occurred. And haven't we altered the "telos" of animals by domestication? As I suggested originally, one might "rectify" this through genetic engineering [p. 14]. As I also suggested, we might re-introduce extinct species (as well as preserve endangered ones) with the help of genetic (including transgenic) mainipulation, and this, too, can be seen as serving "telos." All things considered, the concept of "telos" is not very helpful to the opponent of genetic manipulation.

However, it seens plain that, despite his earlier words, Fox does not genuinely believe that altering an individual's genetic make-up is wrong in itself. Towards the end of his response, he endorses "appropriate" genetic engineering, defined by him as motivated by "ecological forethought, humility, and compassion." I couldn't agree more. Although Fox, in his fourth and last objection, says that I fail to address the need for such a "world-view," I did in fact repeatedly urge that concern and respect for (at least) sentient individuals, in conjunction with extrene caution and humility, should guide every act of genetic manipulation. Sadly, very little concern in this regard has been extended to non-humans. I think Fox would join me in hoping that this will one day change. [8]

Notes

1. Between the Species I/3 (1985), pp. 13-8. Subsequent references will be inserted parenthetically into the text.

2. The saga of the mule now has a fascinating new twist. Chronosomal analysis shows that a foal which resulted from the already extrenely rare fruitful mating of a mule and a jack donkey is part inule, part horse, and part donkey. "Dragon Foal," born in China in 1981, is thought to have a high probability of being fertile. If she is, she may be the first of a new species. All this 
came about by traditional means. See "Dragon Foal: Is This the Birth of a New Species?," Discover (January, 1986), pp. 12-14.

3. Animal Rights and Hunan Morality (Buffalo: Prometheus Books, 1981), PP. 54, 52. However, I have Iny doubts about the advisability of continuing to use this term in arguments with scientists. It is too easy to confuse the new meaning with the original sense. The hostility these scientists show when they discuss "telos," as Fox documents,

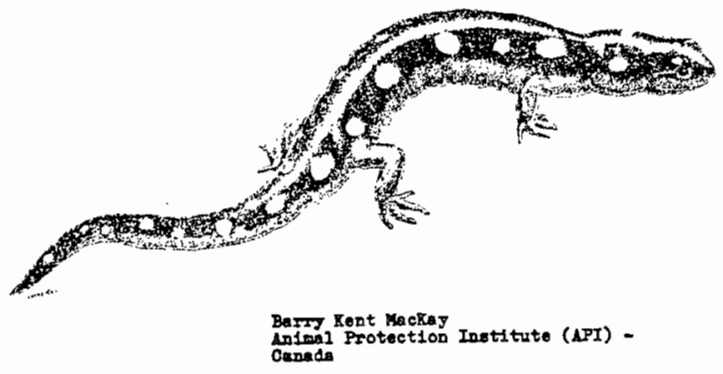

is hardly surprising.

4. Ibid.; p. 55 .

5. Ibid., p. 42 .

6. Ibid., p. 43, emphasis added.

7. Sẹ, @.g.. "U. S. Panel Approves Gene Transplant Guide, UPI Report, Pittsburgh Press $(9 / 24 / 85)$, p. 1 ; and "The Genetic Gamble," Nova (1985, televised by WOED, Pittsburgh, on $11 / 26 / 85)$. The first procedure will be tried on those born without functioning immune systems.

8. Here is an example of a piece of genetic engineering which could develop into something highly appropriate. Bacteria, fungi, and yeasts can now be modified in such a way as to constitute food indistinguishable fran meats in looks, texture, taste, and nutrition. (See "Food of the Future," Science Digest (December, 1985), p. 22.) This food can be grown easily in tanks in any location. The benefits for humans in drought-stricken countries is obvious (and, I might add, this will apply to much of the U.S. in the next century, if the "greenhouse effect" predictions prove to be correct). Much aninal suffering--although, predictably, the scientists involved in these experiments make no mention of this--could be prevented by this technique.

BETWEEN THE SPECIES

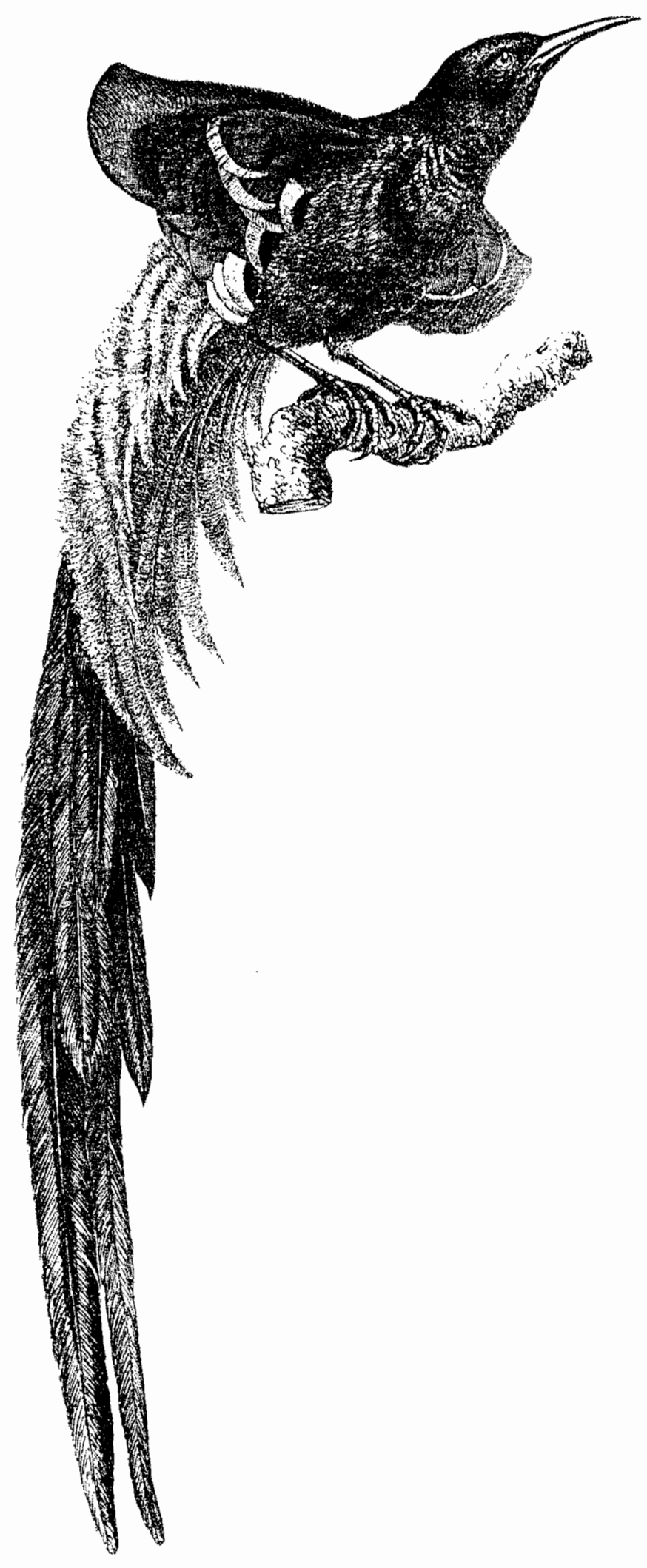

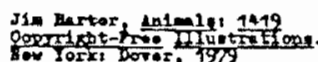

